\title{
ECAR-4802 Fission Gas Activity Criteria for Operation of the AGR- 5/6/7 Experiment in the Advanced Test Reactor
}

Paul A Demkowicz, Cam Binh T Pham

December 2019

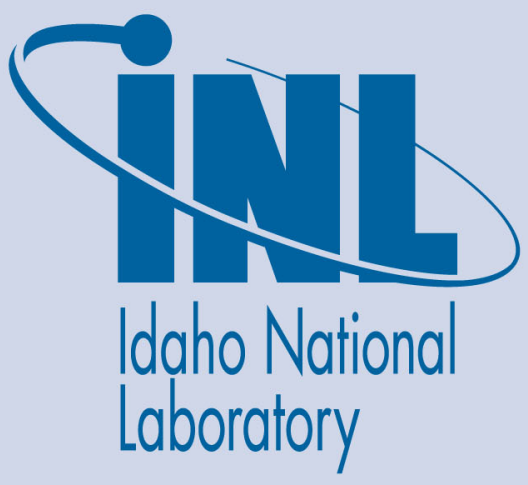

The INL is a U.S. Department of Energy National Laboratory operated by Battelle Energy Alliance 


\title{
ECAR-4802 Fission Gas Activity Criteria for Operation of the AGR-5/6/7 Experiment in the Advanced Test Reactor
}

\author{
Paul A Demkowicz, Cam Binh T Pham
}

December 2019

Idaho National Laboratory Idaho Falls, Idaho 83415

http://www.inl.gov

Prepared for the

U.S. Department of Energy

Under DOE Idaho Operations Office

Contract DE-AC07-05ID14517 
TEM-10200-1

Rev. 08

Title: $\quad$ Test Reactor

$\begin{array}{lllll}\text { ECAR No.: } 4802 & \text { Rev. No.: } 0 & \text { Project No.: } 23841 \quad \text { Date: } 12 / 03 / 2019\end{array}$

\begin{tabular}{|c|l|c|c|}
\hline 1. & $\begin{array}{l}\text { Does this ECAR involve a } \\
\text { Safety SSC? }\end{array}$ & No & $\begin{array}{c}\text { Professional Engineer's Stamp } \\
\text { N/A }\end{array}$ \\
\hline 2. & $\begin{array}{l}\text { Safety SSC } \\
\text { Determination Document } \\
\text { ID }\end{array}$ & $X$ & \multirow{2}{*}{ See LWP-10010 for requirements. } \\
\hline 3. & Engineering Job (EJ) No. & $X$ \\
\hline 4. & SSC ID & $X$ \\
\cline { 1 - 2 } 5. & Building & $X$ \\
\hline 6. & Site Area & $X$ \\
\hline
\end{tabular}

7. Objective/Purpose:

Define action levels for Advanced Gas Reactor (AGR) AGR-5/6/7 experiment flow conditions, based on fission gas monitoring data of the Advanced Test Reactor (ATR) stack.

8. If revision, please state the reason and list sections and/or pages being affected:

Not applicable

9. Conclusions/Recommendations:

Calculations and data are provided to support new measurement-based dose levels for management of the AGR-5/6/7 experiment. Limiting values for ATR stack activity are provided for isotopes that are most likely to increase in activity as a result of particle failures (Kr-87, Kr-88) or transients in the gas flow through the Capsule 1 (Xe-133). The criteria for single-day averages are based on the activity of each isotope that would be required for the total fission gas activity to reach a total dose of $0.0098 \mathrm{mrem} / \mathrm{y}$ if accumulated over 200 days. For $\mathrm{Kr}-87$ and $\mathrm{Kr}-88$, the activities are based on the fission gas release ratios calculated in physics simulations and measured during the AGR-5/6/7 experiment. For Xe-133, the criterion assumes that the fission gas release is dominated by long-lived isotopes, as was observed at the end of Cycle 166A. The net dose restriction is conservatively set at a factor of 10 below the current APAD (1) limit of $0.098 \mathrm{mrem} / \mathrm{y}$.

Proposed stack activity limits for $\mathrm{Kr}-87, \mathrm{Kr}-88$, and $\mathrm{Xe}-133$, to ensure that the total annual dose would be less than $0.0098 \mathrm{mrem} / \mathrm{y}$ if operated at that level for 200 days, are provided below.

\begin{tabular}{|l|c|c|c|}
\hline \multicolumn{1}{|c|}{ Parameter } & \multicolumn{3}{c|}{$\begin{array}{c}\text { Activity at Stack } \\
\text { (Ci/d) }\end{array}$} \\
\hline Isotope & $\mathrm{Kr}-87$ & $\mathrm{Kr}-88$ & $\mathrm{Xe}-133$ \\
\hline Single-day average & 5.1 & 6.0 & 32 \\
\hline 5 points above in 24-hour period & 25.5 & 30.1 & 161 \\
\hline
\end{tabular}


Rev. 08

Fission Gas Activity Criteria for Operation of the AGR-5/6/7 Experiment in the Advanced

Title: $\quad$ Test Reactor

$\begin{array}{llll}\text { ECAR No.: } 4802 & \text { Rev. No.: } 0 & \text { Project No.: } 23841 \quad \text { Date: } 12 / 03 / 2019\end{array}$

\section{CONTENTS}

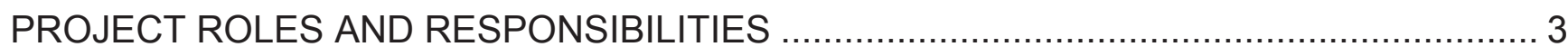

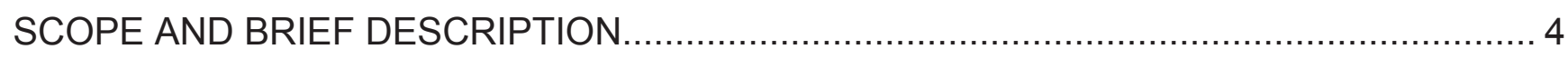

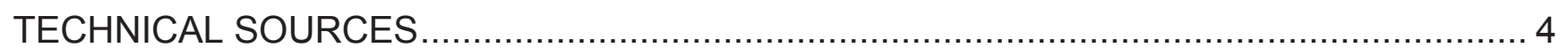

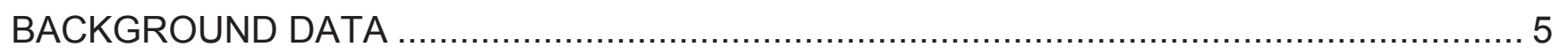

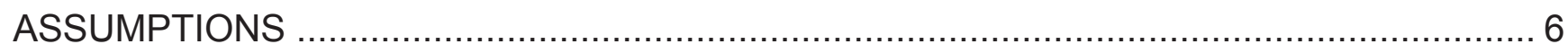

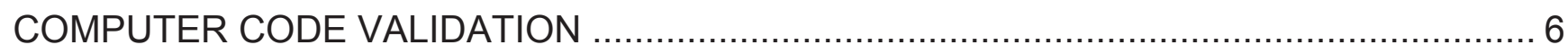

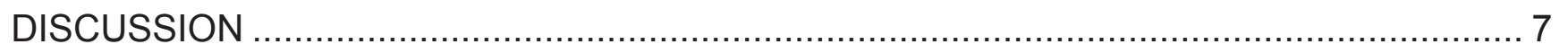

Calculations of Fission Gas Release Rates Based on Previous AGR Experiment Data

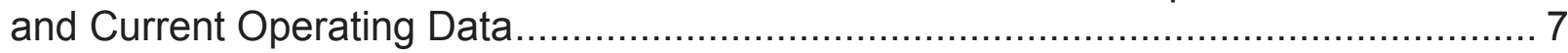

Release Rates Calculated from Release Rate/Birth Rate Ratios .................................. 10

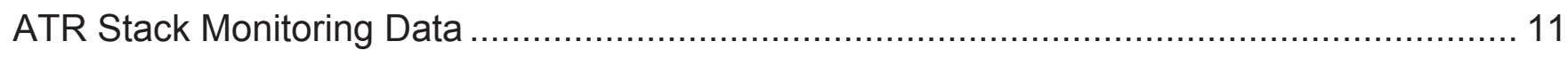

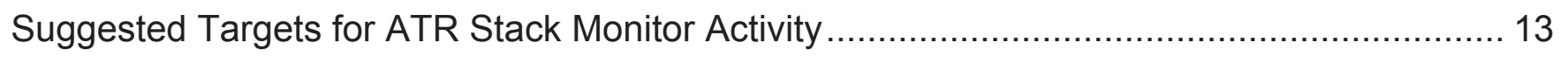

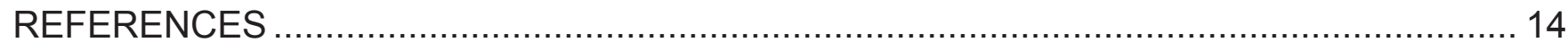


Rev. 08

Fission Gas Activity Criteria for Operation of the AGR-5/6/7 Experiment in the Advanced

Title: $\quad$ Test Reactor

ECAR No.: 4802

Rev. No.: 0

Project No.:

23841

Date: $12 / 03 / 2019$

PROJECT ROLES AND RESPONSIBILITIES

\begin{tabular}{|c|c|c|c|}
\hline Project Role & Name (Typed) & Organization & Pages covered (if applicable) \\
\hline Performer & $\begin{array}{l}\text { Paul Demkowicz, } \\
\text { Binh Pham }\end{array}$ & C600, C220 & All \\
\hline Checker $^{\mathrm{a}}$ & Mitchell Plummer & C220 & All, including SAS \& Excel files \\
\hline Independent Reviewer ${ }^{\mathrm{b}}$ & NA & & \\
\hline CUI Reviewer ${ }^{\mathrm{C}}$ & INL/MIS-19-56800 & & All \\
\hline Manager $^{d}$ & Travis Mitchell & C601 & All \\
\hline Requestor $^{\mathrm{e}}$ & Paul Demkowicz & C600 & All \\
\hline Nuclear Safety ${ }^{\mathrm{e}}$ & NA & & \\
\hline Document Owner ${ }^{\mathrm{e}}$ & Paul Demkowicz & C600 & All \\
\hline
\end{tabular}
a. Confirmation of completeness, mathematical accuracy, and correctness of data and appropriateness of assumptions.
b. Concurrence of method or approach. See definition, LWP-10106.
c. Concurrence with the document's markings in accordance with LWP-11202.
d. Concurrence of procedure compliance. Concurrence with method/approach and conclusion.
e. Concurrence with the document's assumptions and input information. See definition of Acceptance, LWP-10200.

NOTE: $\quad$ Delete or mark "N/A" for project roles not engaged. Include ALL personnel and their roles listed above in the eCR system. The list of the roles above is not all inclusive. If needed, the list can be extended or reduced. 
Rev. 08

Fission Gas Activity Criteria for Operation of the AGR-5/6/7 Experiment in the Advanced

Title: $\quad$ Test Reactor

$\begin{array}{lllll}\text { ECAR No.: } 4802 & \text { Rev. No.: } 0 & \text { Project No.: } 23841 \quad \text { Date: } 12 / 03 / 2019\end{array}$

\section{SCOPE AND BRIEF DESCRIPTION}

This document describes the technical basis for setting action levels for handling of the Advanced Gas Reactor (AGR) AGR-5/6/7 experiment based on fission gas monitoring of the Advanced Test Reactor (ATR) stack. This includes:

- Demonstration that predictions of fission gas release have been consistent with predictions of that behavior based on data from previous experiments, combined with statistical estimates of fuel fabrication defects in the AGR-5/6/7 fuel

- Calculations demonstrating the potential fission gas release if all fuel particles in AGR-5/6/7 Capsule 1 were to begin releasing fission gas, at rates based on release rates observed in previous AGR experiments involving designed-to-fail fuel particles

- Calculations describing the activity of fission gas isotopes in the ATR stack that would yield a total dose of $<0.0098$ mrem at Frenchman's Cabin, for a 200-day period at that release rate

- Data from the ATR stack monitoring system measuring release rates of fission gases produced in the AGR $-5 / 6 / 7$, during periods of relatively low and high release

- Measurements of the system particulate lodine noble gas monitor demonstrating negligible emission of Cs-134, Cs-137, Sr-89, Sr-90, and I-131 in previous AGR experiments of design similar to AGR $-5 / 6 / 7$.

\section{TECHNICAL SOURCES}

Calculations, and source documents, used in this analysis include the following:

- Release rates for the AGR-5/6/7 experiment:

— SAS Enterprise Guide project: "X:ISAS_ProjectsINGNPINDMAS Version 2.0\AGR567\AGR567_Release_Analysis.egp”

- Inputs:

- Release-to-birth behavior of previous experiments (1)

- Calculated birth rates in the AGR-5/6/7 experiment (3)

- Calculated temperatures in the AGR-5/6/7 experiment (7)

- Calculated dose associated with fission gas releases:

- Excel spreadsheet: "AGR-567 Release Ci mRem 166A wide ECAR document.xIsx"

- Calculations incorporate:

- Decay during transport from the AGR-5/6/7 experiment to the ATR stack

- CAP 88 dose conversion factors for ATR stack releases. 
TEM-10200-1

$12 / 19 / 17$

Rev. 08

Fission Gas Activity Criteria for Operation of the AGR-5/6/7 Experiment in the Advanced

Title: $\quad$ Test Reactor

$\begin{array}{lllll}\text { ECAR No.: } 4802 & \text { Rev. No.: } & 0 & \text { Project No.: } 23841 \quad \text { Date: } 12 / 03 / 2019\end{array}$

\section{BACKGROUND DATA}

The Air Permitting Applicability Determination (APAD; 1) approach to management of the AGR-5/6/7 experiment is based on estimates that an annual dose of $\sim 0.098 \mathrm{mrem} / \mathrm{y}$ would be reached if greater than $1 \%$ of the particles in Capsules 1 and 3 were to fail $(\sim 3,600$ particles). Use of that datum as a management action relies on highly uncertain estimates of the number of failed particles within the experiment and dose rates of fission products for which emission from the AGR-5/6/7 experiment is negligible. This document recommends new action limits for the experiment based on monitoring of fission gases released from the experiment that are directly measured in both the AGR-5/6/7 fission product monitoring system (FPMS) and the ATR stack monitoring system.

The isotopes that drive the dose limit for the APAD (1) are Cs-134, Cs-137, Sr-89, Sr-90, and I-131. Table 1 shows the estimated release from the experiment based on these assumptions.

Table 1. Threshold for radioisotope release to remain under $0.098 \mathrm{mrem} / \mathrm{y}$ from the AGR-5/6/7 APAD.

\begin{tabular}{|c|c|}
\hline Radionuclide & $\begin{array}{c}\text { Release } \\
\text { (Ci/y) }\end{array}$ \\
\hline Cs-134 & $7.59 \mathrm{E}-01$ \\
\hline Cs-137 & $5.51 \mathrm{E}-01$ \\
\hline I-131 & $6.92 \mathrm{E}+00$ \\
\hline Sr-89 & $5.52 \mathrm{E}+00$ \\
\hline Sr-90 & $4.51 \mathrm{E}-01$ \\
\hline
\end{tabular}

The AGR-3/4 experiment contained a total of approximately 90,000 particles in 48 compacts. Of these particles, 1,000 were "designed-to-fail" particles with exposed kernels that released fission gases continuously throughout the test (1). Table 2 shows data from the system particulate iodine noble gas monitor (SPING) from 2011 to 2018 (3) for the five isotopes presented in Table 1. The AGR-3/4 experiment began on December 14, 2011, and ended on April 12, 2014. Therefore, calendar years 2012 and 2013 are the two in which the experiment was in the reactor for the entire year. Table 2 also gives the SPING data expressed as a fraction of the activity limits from Table 1 for each respective isotope. For 2012 and 2013, the ratio of the measured SPING activities to the proposed AGR-5/6/7 limits range from approximately $5 \mathrm{E}-7$ to $1 \mathrm{E}-6$ for all isotopes measured. While the AGR-5/6/7 release from Table 1 is predicted based on 3,600 particles and the inventory of U-235 in AGR-5/6/7 particles is about 30\% higher compared to AGR-3/4, the data demonstrate that the release of these elements from the experiment to the stack is negligible. The release of $\mathrm{Cs}, \mathrm{Sr}$, and I isotopes from AGR-5/6/7 are thus considered a poor indicator of dose from the experiment. Fission gas monitoring, and activity levels described in this analysis are suggested as more reliable measurement-based dose management criteria for the experiment, with continued monitoring of the SPING data for the isotopes described in the current APAD (1). 
TEM-10200-1

$12 / 19 / 17$

Rev. 08

Title: $\quad$ Fission Gas $\quad$ Test Reactor

$\begin{array}{lllll}\text { ECAR No.: } 4802 & \text { Rev. No.: } & 0 & \text { Project No.: } 23841 \quad \text { Date: } 12 / 03 / 2019\end{array}$

Table 2. Total annual activity of several isotopes measured by ATR SPING in curies per year, and the activity expressed as a fraction of the limiting values in Table 1. The maximum and minimum values of the fractions for Years 2012 and 2013 are highlighted in gray.

\begin{tabular}{|c|c|c|c|c|c|c|c|c|}
\hline \multirow[b]{2}{*}{ Radionuclide } & \multicolumn{8}{|c|}{$\begin{array}{l}\text { Activity Measured by SPING } \\
(\mathrm{Ci} / \mathrm{y})\end{array}$} \\
\hline & 2011 & 2012 & 2013 & 2014 & 2015 & 2016 & 2017 & 2018 \\
\hline Cs-134 & NR & NR & NR & NR & NR & NR & $3.2 \mathrm{E}-07$ & NR \\
\hline Cs-137 & $9.3 \mathrm{E}-07$ & $7.9 \mathrm{E}-07$ & $6.0 \mathrm{E}-07$ & $2.7 \mathrm{E}-06$ & $1.2 \mathrm{E}-06$ & 7.6E-07 & 2.6E-07 & NR \\
\hline |-131 & $2.4 \mathrm{E}-06$ & $3.8 \mathrm{E}-06$ & $5.0 \mathrm{E}-06$ & $4.9 \mathrm{E}-06$ & $6.6 \mathrm{E}-07$ & $1.2 \mathrm{E}-06$ & $1.8 \mathrm{E}-06$ & $2.2 \mathrm{E}-06$ \\
\hline Sr-89 & NR & NR & NR & NR & NR & NR & NR & NR \\
\hline \multirow[t]{2}{*}{ Sr-90 } & $6.0 \mathrm{E}-05$ & 2.0E-07 & $3.6 \mathrm{E}-07$ & $2.3 \mathrm{E}-07$ & $1.1 \mathrm{E}-07$ & 2.6E-07 & $1.2 \mathrm{E}-07$ & $8.2 \mathrm{E}-08$ \\
\hline & \multicolumn{8}{|c|}{ Activity as a Fraction of the AGR-5/6/7 APAD Limit } \\
\hline Radionuclide & 2011 & 2012 & 2013 & 2014 & 2015 & 2016 & 2017 & 2018 \\
\hline Cs-134 & NR & $N R$ & NR & NR & $N R$ & NR & $4.2 \mathrm{E}-07$ & NR \\
\hline Cs-137 & $1.7 \mathrm{E}-06$ & $1.4 \mathrm{E}-06$ & 1.1E-06 & $4.8 \mathrm{E}-06$ & 2.2E-06 & $1.4 \mathrm{E}-06$ & 4.6E-07 & NR \\
\hline I-131 & $3.4 \mathrm{E}-07$ & $5.4 \mathrm{E}-07$ & 7.3E-07 & $7.1 \mathrm{E}-07$ & $9.5 \mathrm{E}-08$ & 1.7E-07 & $2.6 \mathrm{E}-07$ & 3.2E-07 \\
\hline Sr-89 & NR & NR & NR & NR & NR & NR & NR & NR \\
\hline \multirow[t]{3}{*}{ Sr-90 } & $1.3 \mathrm{E}-04$ & $4.4 \mathrm{E}-07$ & $7.9 \mathrm{E}-07$ & $5.0 \mathrm{E}-07$ & $2.5 \mathrm{E}-07$ & $5.9 \mathrm{E}-07$ & 2.7E-07 & $1.8 \mathrm{E}-07$ \\
\hline & & Max & $1.4 \mathrm{E}-06$ & & & & & \\
\hline & & Min & 4.4E-07 & & & & & \\
\hline
\end{tabular}

\section{ASSUMPTIONS}

Assumptions associated with calculations of fission gas activity associated with particle failures in the AGR-5/6/7 experiment are described in the referenced documents.

\section{COMPUTER CODE VALIDATION}
A. Computer type: Dell desktop computer
B. Operating System and Version: Windows 10
C. Computer program names and revision: SAS Enterprise Guide, Microsoft Excel
D. Inputs and Outputs are described in the text 
TEM-10200-1

$12 / 19 / 17$

Rev. 08

Fission Gas Activity Criteria for Operation of the AGR-5/6/7 Experiment in the Advanced

Title: $\quad$ Test Reactor

$\begin{array}{lllll}\text { ECAR No.: } 4802 & \text { Rev. No.: } & 0 & \text { Project No.: } 23841 \quad \text { Date: } 12 / 03 / 2019\end{array}$

E. Evidence of, or reference to, computer program validation:

- SAS Enterprise Guide project data manipulation was reviewed via:

- Examination of code used to query the Nuclear Data Management and Analysis System (NDMAS; 4) database, and other input files

- Comparison of data tables imported to the SAS Enterprise Guide Project with the source files

- Comparison with sample calculations performed using Mathcad (PTC)

- Microsoft Excel Calculations were reviewed via:

- Examination of cell-based equations

- Comparison with sample calculations performed using Mathcad (PTC)

F. Bases supporting application of the computer program to the specific physical problem:

- SAS Enterprise Guide is used to collect and organize time series data from disparate sources, and to access NQA-1 qualified data from NDMAS

- Excel is used for summation, averaging, and visualization of data collected from the SAS Enterprise Guide project (see Item E, first bullet).

\section{DISCUSSION}

Suggested criteria for management decisions regarding operation of the AGR-5/6/7 experiment are based on a combination of (a) calculations demonstrating the potential for fission gas releases from AGR-5/6/7 based on operating conditions and information from previous AGR experiments, and (b) real-time monitoring of fission gases in the ATR stack.

\section{Calculations of Fission Gas Release Rates Based on Previous AGR Experiment Data and Current Operating Data}

Continuous fission gas release rates from the AGR-5/6/7 experiment have been predicted using data collected from the previous AGR-1 and AGR-3/4 experiments and the calculated birth rates of fission gases in the AGR-5/6/7 experiment. The predicted values agree well with values measured during monitoring of the experiment (see Figure 1 and Figure 2). This has been demonstrated for cycles up through ATR Cycle 164B as reported in Reference 5. Calculations performed for this analysis (Cycle 166A in Figure 1 and Figure 2) indicate that measured releases from Capsule 1 have increased significantly relative to predicted values, but were generally within an order of magnitude during the short periods where the capsule was operated with a relatively high flow rate (from approximately August 1 to August 15, 2019). In general, during periods of stable gas flow, where the fission gas release rates can be more reliably calculated, the measured release from Capsule 1 has been within a factor of five of the predicted values. These calculations are thus considered a reasonable means of estimating the effect of higher numbers of particle failures in the experiment, to provide bounds on likely fission gas release rates to the ATR stack for different fuel failure scenarios. 
TEM-10200-1

$12 / 19 / 17$

Rev. 08

ENGINEERING CALCULATIONS AND ANALYSIS

Page 8 of 15

Fission Gas Activity Criteria for Operation of the AGR-5/6/7 Experiment in the Advanced

Title: $\quad$ Test Reactor

$\begin{array}{lllll}\text { ECAR No.: } 4802 & \text { Rev. No.: } & 0 & \text { Project No.: } 23841 \quad \text { Date: } 12 / 03 / 2019\end{array}$

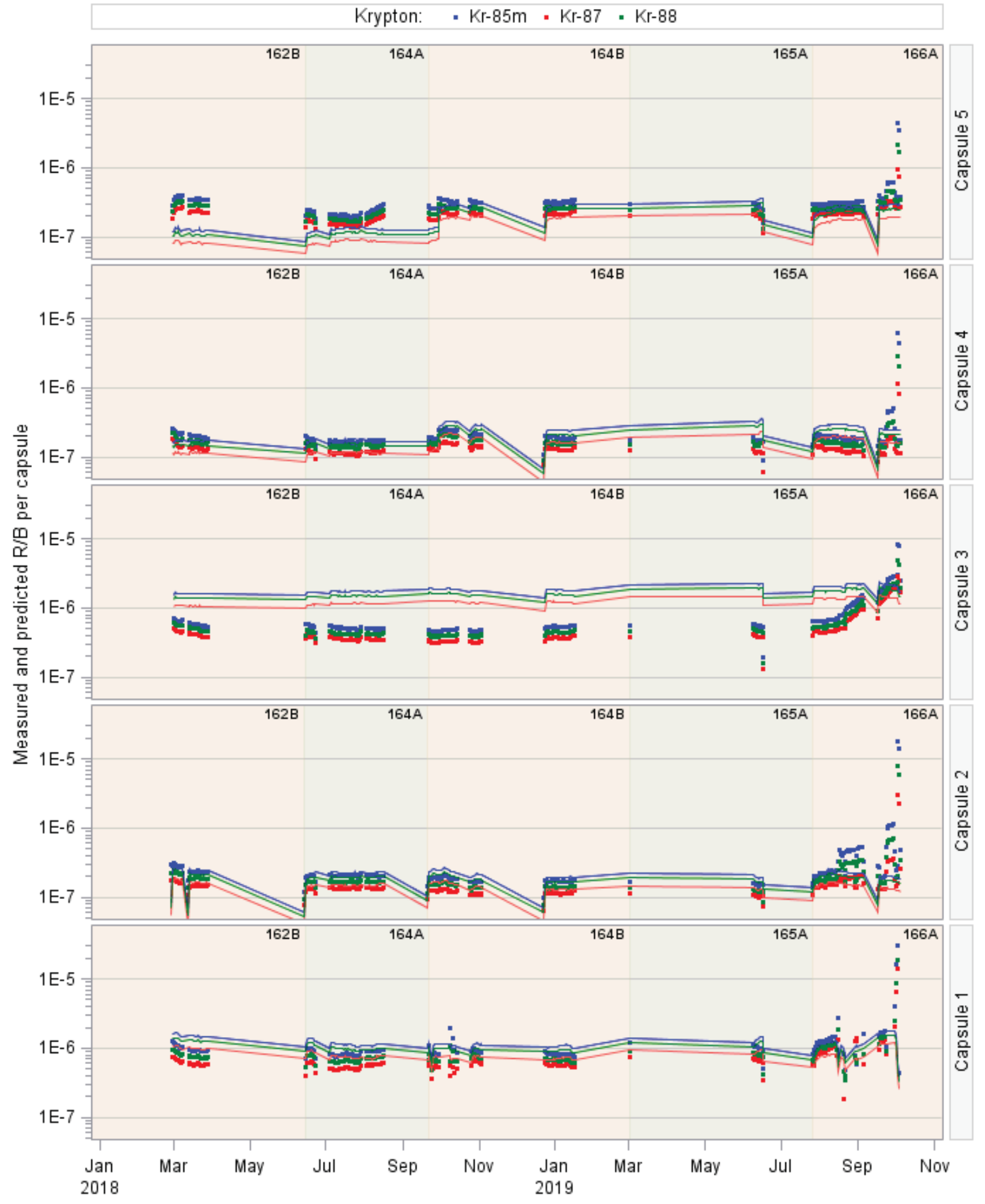

Figure 1. Krypton gas isotope activities measured at the FPMS detector, compared to values calculated based on previous experimental data and statistics of fuel fabrication. Values for cycles prior to

Cycle 166A are documented in Reference 5. Values for Cycle 166A were calculated as described in the text. 
TEM-10200-1

$12 / 19 / 17$

Rev. 08

ENGINEERING CALCULATIONS AND ANALYSIS

Page 9 of 15

Fission Gas Activity Criteria for Operation of the AGR-5/6/7 Experiment in the Advanced

Title: $\quad$ Test Reactor

$\begin{array}{lllll}\text { ECAR No.: } 4802 & \text { Rev. No.: } & 0 & \text { Project No.: } 23841 \quad \text { Date: } 12 / 03 / 2019\end{array}$

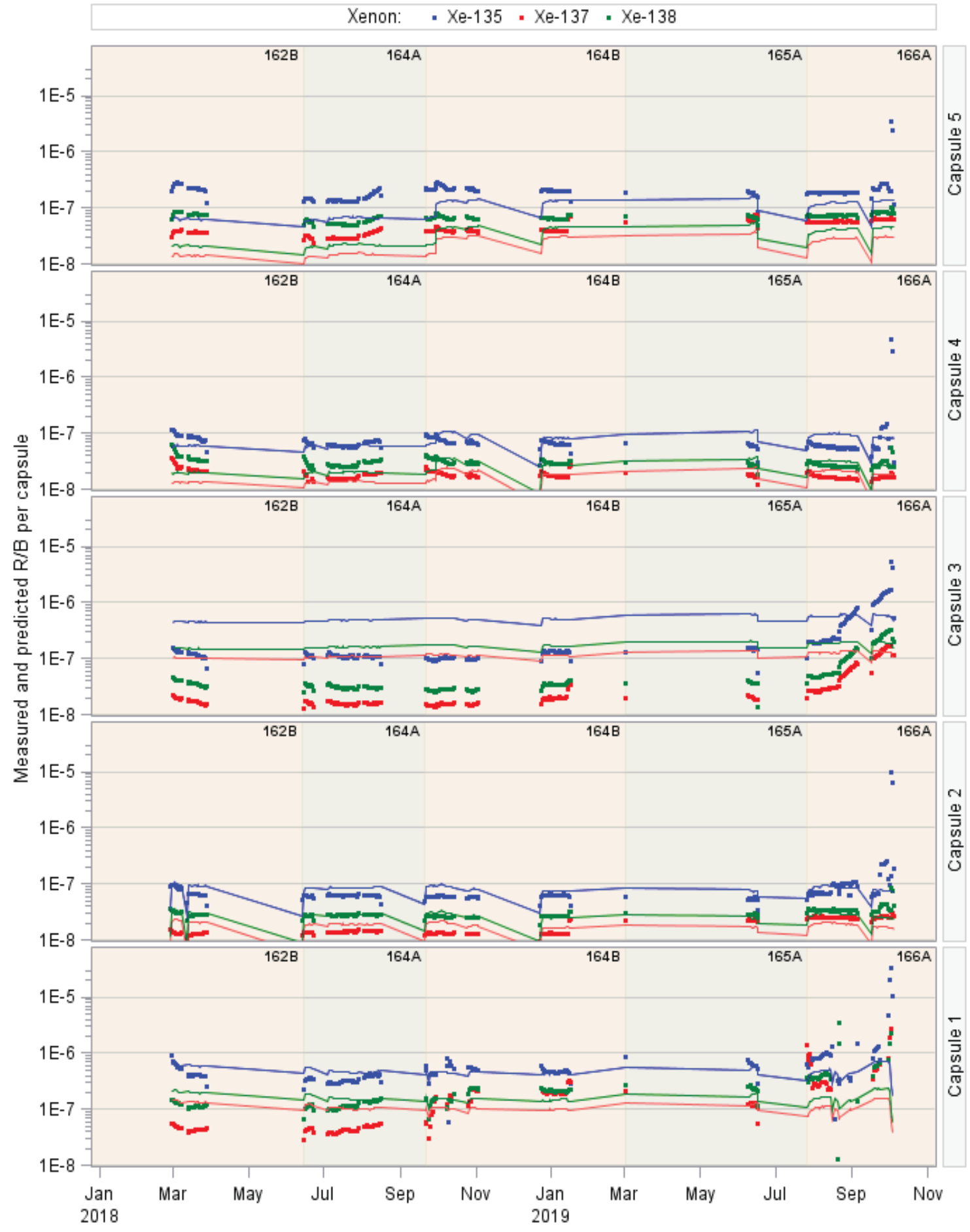

Figure 2. Xenon gas isotopes activities measured at the FPMS detector, compared to values calculated based on previous experimental data and statistics of fuel fabrication. Values for cycles prior to Cycle 166A are documented in Reference 5. Values for Cycle 166A were calculated as described in the text. 
TEM-10200-1

$12 / 19 / 17$

Rev. 08

ENGINEERING CALCULATIONS AND ANALYSIS

Page 10 of 15

Fission Gas Activity Criteria for Operation of the AGR-5/6/7 Experiment in the Advanced

Title: $\quad$ Test Reactor

$\begin{array}{lllll}\text { ECAR No.: } 4802 & \text { Rev. No.: } & 0 & \text { Project No.: } 23841 \quad \text { Date: } 12 / 03 / 2019\end{array}$

\section{Release Rates Calculated from Release Rate/Birth Rate Ratios}

To describe the potential effect of various particle failure scenarios on fission gas dose from ATR, release rates and consequent dose from the experiment were calculated based on the following information and assumptions:

- Fission gas birth rates were calculated using the methodology used for previous AGR experiments, as described in Reference 6.

- Capsule temperatures were calculated for Cycle 166A using the methodology described in Reference 7.

- Fission product release-to-birth ratios were calculated as described in Reference 5.

- Radioactive decay in piping between the experiment FPMS and the ATR stack was calculated assuming a residence time of 1.2 hours. The residence time is based on the maximum average, per cycle, daily sweep gas flow $\left(295 \mathrm{~cm}^{3} \mathrm{~s}^{-1}\right)$ through the experiment and exit line volume of $21,500 \mathrm{~cm}^{3}$ (8).

- Activity to dose conversions provided in Reference 9 were based on calculations with the CAP-88, using the methodology described in Reference 10.

Results of two scenarios are used to inform decisions regarding the AGR-5/6/7 experiment:

- Assume failure of all fuel particles in Capsule 1, with resulting per-particle release to birth ratio determined for the AGR-3/4 experiment that was designed to measure that ratio. This provides a maximum release rate to be compared with the maximum dose.

- Calculate the number of fuel particle failures sufficient to produce a dose of $0.0098 \mathrm{mrem}$ from the ATR stack.

Table 3 shows the total dose from release of fission gas in Capsule 1 for a particle fraction of $100 \%$, calculated assuming 200 days of operation in a year. The corresponding activity of each isotope released from the capsule is given in the fourth column. The calculated values include the effect of decay during transport from the experiment to the ATR stack, so isotopes with relatively short half-lives, like Xe-135m ( $\left.t_{1 / 2}=15 \mathrm{~min}\right)$, are not significant contributors because their activity would be reduced by a factor of at least 25 due to decay. The sum of the dose from all isotopes is $0.057 \mathrm{mrem} / \mathrm{y}$. A similar analysis is shown in the fifth and sixth columns assuming $17 \%$ particle failure in Capsule $1(\sim 53,000$ particles). The total dose is $0.0098 \mathrm{mrem} / \mathrm{y}$, a factor of $\sim$ ten below the APAD (1) recommended limit of $0.098 \mathrm{mrem} / \mathrm{y}$. 
TEM-10200-1

$12 / 19 / 17$

Rev. 08

Title:

Fission Gas Activity Criteria for Operation of the AGR-5/6/7 Experiment in the Advanced

Test Reactor

ECAR No.: 4802

Rev. No.: 0

Project No.:

23841

Date: $12 / 03 / 2019$

Table 3. Dose and activity contribution calculated for two different levels of particle failure in AGR-5/6/7 Capsule 1. Isotopes contributing more than $5 \%$ of the total dose are highlighted in gray.

\begin{tabular}{|c|c|c|c|c|c|c|}
\hline \multirow[b]{2}{*}{ Isotope } & \multirow[b]{2}{*}{$\begin{array}{l}\text { Half-life } \\
\text { (minutes) }\end{array}$} & \multicolumn{2}{|c|}{$\begin{array}{l}\text { 100\% Capsule-1 Particle } \\
\text { Failure }\end{array}$} & \multicolumn{2}{|c|}{$\begin{array}{l}\text { 17.1\% Capsule-1 Particle } \\
\text { Failure }\end{array}$} & \multirow[b]{2}{*}{$\begin{array}{l}\text { Percent } \\
\text { of Total }\end{array}$} \\
\hline & & $\begin{array}{c}\text { Dose } \\
\text { (mrem/y) }\end{array}$ & $\begin{array}{l}\text { Activity } \\
\text { (Ci/d) }\end{array}$ & $\begin{array}{c}\text { Dose } \\
\text { (mrem/y) }\end{array}$ & $\begin{array}{l}\text { Activity } \\
\text { (Ci/d) }\end{array}$ & \\
\hline $\mathrm{Kr}-85 \mathrm{~m}$ & 268.80 & $8.2 \mathrm{E}-04$ & $1.0 \mathrm{E}+01$ & $1.4 \mathrm{E}-04$ & $1.8 \mathrm{E}+00$ & $1.4 \%$ \\
\hline $\mathrm{Kr}-87$ & 76.30 & $6.6 \mathrm{E}-03$ & $3.0 \mathrm{E}+01$ & 1.1E-03 & $5.1 \mathrm{E}+00$ & $11.4 \%$ \\
\hline $\mathrm{Kr}-88$ & 170.40 & 4.7E-02 & $3.5 E+01$ & 8.1E-03 & $6.0 \mathrm{E}+00$ & $82.4 \%$ \\
\hline $\mathrm{Kr}-89$ & 3.15 & 7.6E-10 & $9.5 E-05$ & 1.3E-10 & 1.6E-05 & $0.0 \%$ \\
\hline $\mathrm{Kr}-90$ & 0.54 & $0.0 \mathrm{E}+00$ & 5.4E-38 & $0.0 \mathrm{E}+00$ & $9.2 E-39$ & $0.0 \%$ \\
\hline $\mathrm{Xe}-131 \mathrm{~m}$ & 17049.60 & 3.4E-08 & $6.1 \mathrm{E}-03$ & 5.8E-09 & 1.0E-03 & $0.0 \%$ \\
\hline Xe-133 & 7549.92 & 5.9E-05 & $2.7 E+00$ & 1.0E-05 & 4.6E-01 & $0.1 \%$ \\
\hline Xe-135 & 548.40 & $1.8 \mathrm{E}-03$ & $1.2 \mathrm{E}+01$ & $3.1 \mathrm{E}-04$ & $2.1 \mathrm{E}+00$ & $3.2 \%$ \\
\hline Xe-135m & 15.29 & $1.0 \mathrm{E}-05$ & $1.3 E+00$ & $1.8 \mathrm{E}-06$ & 2.3E-01 & $0.0 \%$ \\
\hline Xe-137 & 3.82 & 2.4E-09 & 8.4E-04 & 4.0E-10 & 1.4E-04 & $0.0 \%$ \\
\hline Xe-138 & 14.08 & 8.1E-04 & $5.3 E+00$ & 1.4E-04 & 9.0E-01 & $1.4 \%$ \\
\hline Xe-139 & 0.66 & $0.0 E+00$ & 8.6E-31 & $0.0 \mathrm{E}+00$ & $1.5 \mathrm{E}-31$ & $0.0 \%$ \\
\hline Sum, all isotopes & - & 5.7E-02 & $9.7 E+01$ & $9.80 \mathrm{E}-03$ & $1.7 \mathrm{E}+01$ & $100.0 \%$ \\
\hline
\end{tabular}

The dominant isotopes for dose are $\mathrm{Kr}-87$ and $\mathrm{Kr}-88$ ( $\mathrm{t}_{1 / 2}=1.3$ hours and 2.8 hours, respectively). Longer-lived fission products, $\mathrm{Xe}-135$ ( $\mathrm{t}_{1 / 2}=9 \mathrm{hrs}$.) and Xe-133 ( $\mathrm{t}_{1 / 2}=126$ hours), while not significantly contributing to overall dose, are included in this analysis because intermittent flow through a capsule can cause large peaks in their activity, and those isotopes exhibited some of the most significant activity increases in the ATR stack at the end of Cycle 166A.

\section{ATR Stack Monitoring Data}

The ATR stack monitoring system provides data on the activity of fission gases emitted during reactor operations, including emissions from the AGR-5/6/7 experiment. Figure 3 shows activity levels at the ATR stack monitor (11) at the end of Cycle 166A for several isotopes (reported activities less than zero were converted to a value of zero). These data include a 1-week period in which the AGR-5/6/7 Capsule 1 exit line was closed (September 24 to September 30) and there was negligible activity detected in the capsule gross gamma detector. This region can be considered the background level seen in the stack during normal ATR operations. From September 30 to October 3 there was a significant increase in fission gas activity coming from Capsule 1 while the capsule was being purged with about $3 \mathrm{sccm}$ of sweep gas. From October 3 to 12:00 PM on October 4, the Capsule 1 exit line was again closed. Finally, from 12:00 PM on October 4 to October 6 the Capsule 1 exit line valve was opened, allowing about $12 \mathrm{sccm}$ of leadout flow to exit through the FPMS, causing the highest readings of the cycle on the Capsule 1 gross gamma detector and also in the ATR stack monitor. 
TEM-10200-1

$12 / 19 / 17$

Rev. 08

ENGINEERING CALCULATIONS AND ANALYSIS

Page 12 of 15

Fission Gas Activity Criteria for Operation of the AGR-5/6/7 Experiment in the Advanced

Title: $\quad$ Test Reactor

ECAR No.: 4802

$\begin{array}{lll}\text { Rev. No.: } & 0 & \text { Project No.: } \\ & 23841\end{array}$

Date: $12 / 03 / 2019$

$\mathrm{Kr}-87$

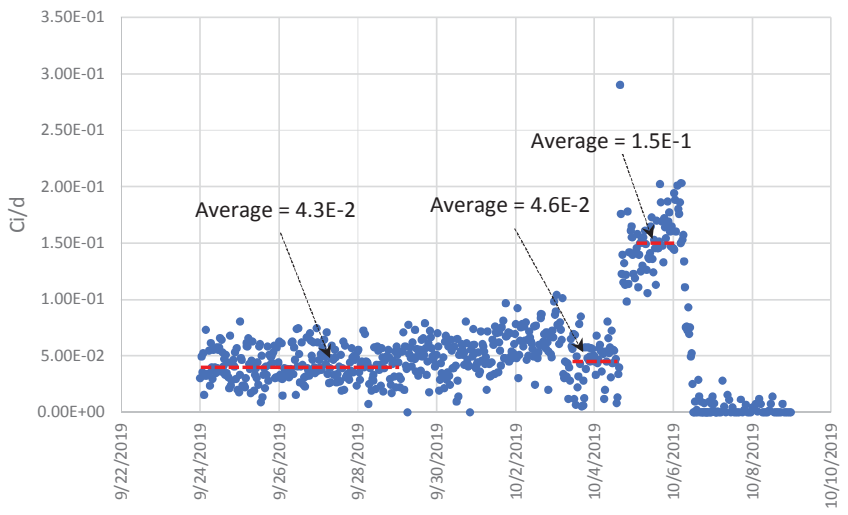

$\mathrm{Xe}-133$

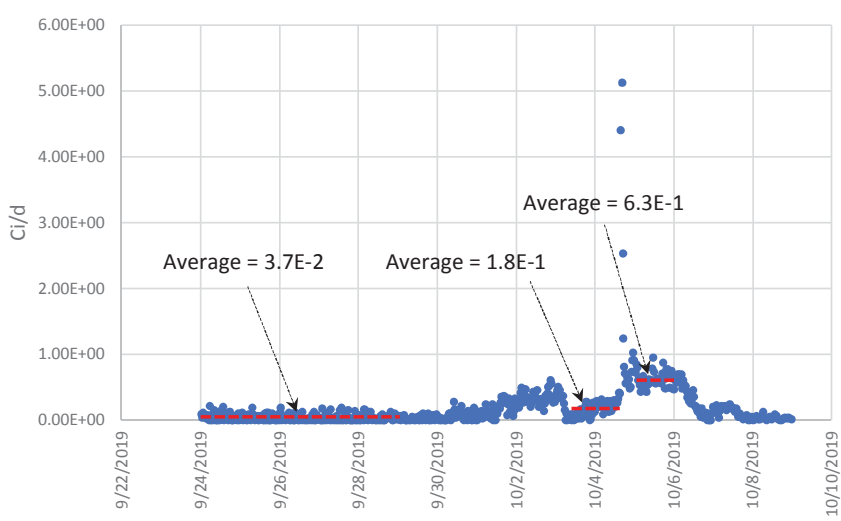

$\mathrm{Kr}-88$

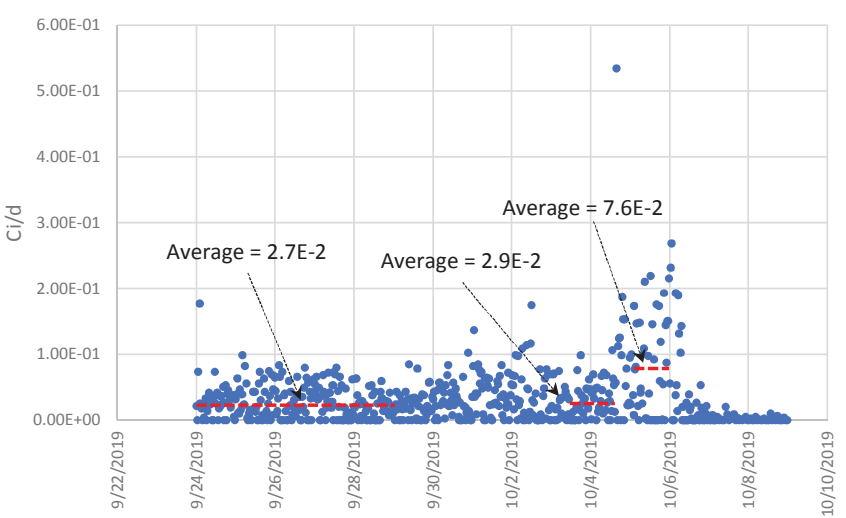

$\mathrm{Xe}-135$

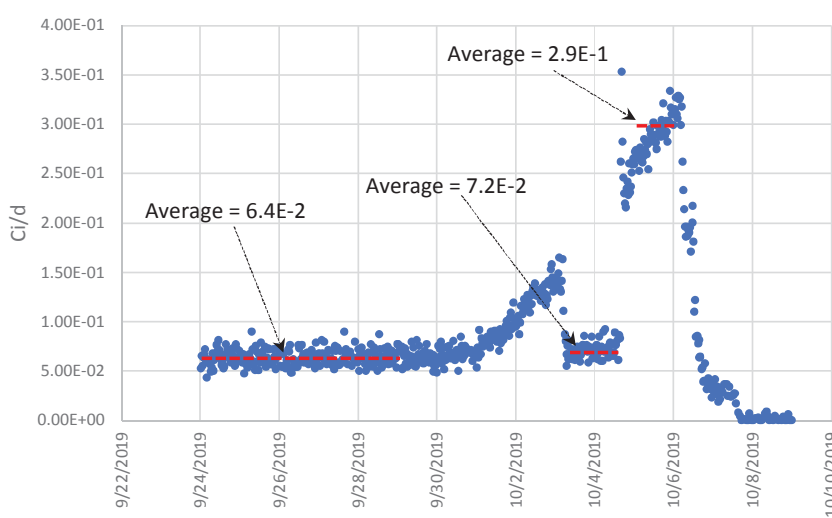

Figure 3. ATR stack activity levels for selected isotopes. 
TEM-10200-1

$12 / 19 / 17$

Rev. 08

Fission Gas Activity Criteria for Operation of the AGR-5/6/7 Experiment in the Advanced

Title:

Test Reactor

ECAR No.: 4802

Rev. No.: 0

Project No.:

23841

Date: $12 / 03 / 2019$

Table 4 gives the average activity values for specific time periods for each isotope shown in Figure 3. It also repeats the daily released activity of each isotope that corresponds to a total dose (all isotopes) of $0.0098 \mathrm{mrem} / \mathrm{y}$ and $0.12 \mathrm{mrem} / \mathrm{y}$ from Table 3.

Table 4. ATR stack monitor data (averages over specific periods) and corresponding activities that would result in the stated dose rates (from Table 3).

\begin{tabular}{|l|c|c|c|c|}
\hline \multirow{2}{*}{\multicolumn{1}{c|}{ Parameter }} & \multicolumn{4}{c|}{$\begin{array}{c}\text { Activity } \\
\text { (Ci/d) }\end{array}$} \\
\cline { 2 - 5 } & $\mathrm{Kr}-87$ & $\mathrm{Kr}-88$ & $\mathrm{Xe}-133$ & $\mathrm{Xe}-135$ \\
\hline Average 9/24-9/29 (background) & $4.3 \mathrm{E}-02$ & $2.7 \mathrm{E}-02$ & $3.7 \mathrm{E}-02$ & $6.4 \mathrm{E}-02$ \\
\hline Average 10/3-10/4 (isolation) & $4.6 \mathrm{E}-02$ & $2.9 \mathrm{E}-02$ & $1.8 \mathrm{E}-01$ & $7.2 \mathrm{E}-02$ \\
\hline Average 10/5 (highest day) & $1.5 \mathrm{E}-01$ & $7.6 \mathrm{E}-02$ & $6.3 \mathrm{E}-01$ & $2.9 \mathrm{E}-01$ \\
\hline Peak 10/4-10/6 & $2.9 \mathrm{E}-01$ & $5.4 \mathrm{E}-01$ & $5.1 \mathrm{E}+00$ & $3.5 \mathrm{E}-01$ \\
\hline Activity to reach 0.0098 mrem/y & $5.1 \mathrm{E}+00$ & $6.0 \mathrm{E}+00$ & $4.6 \mathrm{E}-01$ & $2.1 \mathrm{E}+00$ \\
\hline $\begin{array}{l}\text { Activity to reach 0.057 mrem/y } \\
\text { (100\% failure in Capsule 1) }\end{array}$ & $3.0 \mathrm{E}+01$ & $3.5 \mathrm{E}+01$ & $2.7 \mathrm{E}+00$ & $1.2 \mathrm{E}+01$ \\
\hline
\end{tabular}

It can be observed from the Capsule 1 fission gas release data late in Cycle 166A that the measured activity of the longer-lived fission products (e.g., Xe-133 and Xe-135) increases to a greater extent relative to the shorter-lived fission products. It is believed that this is due to accumulation of these isotopes in the capsule when there is zero or insufficient flow to purge them for several days, followed by release of the stored activity when they are purged from the capsule over several hours to several days. Physics calculations and past behavior indicated that the high activity of these isotopes in the stack (relative to the calculated release from the capsule) is a temporary increase that would not be sustained over many days. To set limits on the release rate of $\mathrm{Xe}-133$ that would result in isolation of Capsule 1, we therefore assume a scenario in which the ratios of isotopes reflects the behavior seen near the end of Cycle 166A (October 5), where fission gas release activity was dominated by the longer-lived isotopes. In that state, activities of $\mathrm{Xe}-133$ and $\mathrm{Xe}-135$ were similar, and $\mathrm{Xe}-133$ activity was five to eight times greater than activities of $\mathrm{Kr}-87$ and $\mathrm{Kr}-88$ (Figure 3). Using $\mathrm{Xe}-133$ as an indicator isotope for that mixture of $\mathrm{Kr}-87, \mathrm{Kr}-88$, $\mathrm{Xe}-133$, and $\mathrm{Xe}-135$, a $\mathrm{Xe}-133$ release rate of 32 $\mathrm{Ci} /$ day would have to be sustained for 200 days to produce the suggested dose limit.

\section{Suggested Targets for ATR Stack Monitor Activity}

Table 5 provides suggested limiting values for stack activity, for isotopes that are most likely to increase in activity as a result of particle failures $(\mathrm{Kr}-87, \mathrm{Kr}-88)$ or transients in the gas flow through the Capsule 1 (Xe-133). The criteria for single-day averages are based on the activity of each isotope that would be required for the total activity (all isotopes in Table 3) to reach a total dose of $0.0098 \mathrm{mrem} / \mathrm{y}$ if accumulated over 200 days. For $\mathrm{Kr}-87$ and $\mathrm{Kr}-88$, the activities are based on the fission gas release ratios calculated in physics simulations and measured during the AGR-5/6/7 experiment. For Xe-133, the criterion assumes that the fission gas release is dominated by long-lived isotopes, as was observed at the end of Cycle 166A. The net dose restriction is conservatively set at a factor of 10 below the current APAD (1) limit of $0.098 \mathrm{mrem} / \mathrm{y}$. 
TEM-10200-1

$12 / 19 / 17$

Rev. 08

Fission Gas Activity Criteria for Operation of the AGR-5/6/7 Experiment in the Advanced

Title: $\quad$ Test Reactor

$\begin{array}{lllll}\text { ECAR No.: } 4802 & \text { Rev. No.: } 0 & \text { Project No.: } 23841 \quad \text { Date: } 12 / 03 / 2019\end{array}$

The limit for temporary single-point excursions (a total of 5 points above this limit in a 24-hour period) in Table 5 is set at five times the single-day average value. If this condition is met, it would prompt a single-day average to be calculated to determine if the capsule should be isolated.

Table 5. Proposed stack activity limits for $\mathrm{Kr}-87, \mathrm{Kr}-88$, and $\mathrm{Xe}-133$, to ensure that the total annual dose would be less than $0.0098 \mathrm{mrem} / \mathrm{y}$ if operated at that level for 200 days.

\begin{tabular}{|l|c|c|c|}
\multicolumn{1}{|c|}{ Parameter } & \multicolumn{3}{c|}{$\begin{array}{c}\text { Activity at Stack } \\
\text { (Ci/d) }\end{array}$} \\
\hline Isotope & $\mathrm{Kr}-87$ & $\mathrm{Kr}-88$ & Xe-133 \\
\hline Single-day average & 5.1 & 6.0 & 32.2 \\
\hline 5 points above in 24-hour period & 25.5 & 30.1 & 161 \\
\hline
\end{tabular}

While the specified criteria are determined based on 200-day release periods, the action levels are considerably more conservative than indicated by the 10 -fold ratio to the air permitting limit, because these levels would result in isolation of the experiment (i.e., no more gas flowing in or out, essentially ceasing all fission gas release to the stack). The resulting annual dose would thus be much lower than the specified level of 0.0098 mrem, since the experiment would need to release these daily activities for 200 days to achieve that dose.

Allowing Capsule 1 fission gas to diffuse into the leadout and be removed by the excess flow from the remaining capsules will result in a longer residence time prior to reaching the ATR stack. Assuming the highest average, per cycle, flow rate through the leadout of $52 \mathrm{~cm}^{3} \mathrm{~min}^{-1}$, the residence time would be on the order of 9 hours in the $\sim 30-\mathrm{L}$ leadout volume. That additional decay would eliminate most of the isotopic activity, except for that of Xe-133 and Xe-135. Comparing to Cycle 166A, this mode of operation would most closely resemble the period when the capsule was isolated from October 3 to 12:00 PM on October 4.

\section{REFERENCES}

1. Air Permitting Applicability Determination, INL-17-007 Rev. 1, 11-06-19 draft.

2. Pham, B., J. Einerson, D. Scates, J. Maki, and D. Petti. 2014. "AGR-1, AGR-2 and AGR-3/4 Release-to-Birth Ratio Data Analysis.” INL/EXT-14-32970, Idaho National Laboratory.

3. Radiation and Effluent Waste Report - ATR Stack Effluents monthly reports 2018-2019, provided in mail from E.D. King to Paul Demkowicz, dated: Nov 5, 2019, Subject: RE: References for ECAR documenting activity limits for management of AGR 5/6/7 experiment.

4. Hull, L.C. 2015. "Nuclear Data Management and Analysis System Plan." PLN-2709, Rev. 4, Idaho National Laboratory, March 12, 2015.

5. Pham, B. and D. Scates. 2019. "AGR-5/6/7 Release-to-Birth Ratio Data Analysis for Cycles 162B, 163A, 164A, and 164B." INL/EXT-19-54457, Idaho National Laboratory.

6. Sterbentz, J. W., "JMOCUP As Run Daily Depletion Calculation for the AGR 3/4 Experiment in the ATR Northeast Flux Trap." ECAR-2753, Rev. 1, Idaho National Laboratory, July 25, 2015. 
Rev. 08

Fission Gas Activity Criteria for Operation of the AGR-5/6/7 Experiment in the Advanced

Title: $\quad$ Test Reactor

$\begin{array}{lllll}\text { ECAR No.: } 4802 & \text { Rev. No.: } 0 & \text { Project No.: } 23841 & \text { Date: } 12 / 03 / 2019\end{array}$

7. Hawkes, G. L., J. W. Sterbentz, and M. Plummer. 2019. "Thermal Model Details and Description of the AGR-5/6/7 Experiment.” ICAPP 2019 - International Congress on Advances in Nuclear Power Plants, France, Juan-les-pins, May 12-15, 2019.

8. Email from J. Shaw to E. D. King, dated Wednesday, October 16, 2019, 3:13:38 PM; Subject: AGR Gas Line.

9. Email from A. J. Sondrup to E. D. King, dated: Wednesday, August 23, 2017, 3:51 PM, Subject: Experiment AGR-5/6/7 Radionuclide List for CAP-88 Modeling.

10. Sondrup, A. J. 2019, Idaho National Laboratory CY-2018 National Emission Standards for Hazardous Air Pollutants Analysis, Methodology and Results for Radionuclides. Idaho National Laboratory.

11. ATR stack monitoring data (“ASM-20191017-092419-100819.csv") provided in email from Julie Bown to Paul Demkowicz, dated: Oct 17, 2019, Subject: RE: Data Needed. 